\title{
Retrieval of sulphur dioxide from the infrared atmospheric sounding interferometer (IASI)
}

\author{
L. Clarisse ${ }^{1}$, D. Hurtmans ${ }^{1}$, C. Clerbaux ${ }^{1,2}$, J. Hadji-Lazaro ${ }^{2}$, Y. Ngadi $^{1}$, and P.-F. Coheur ${ }^{1}$ \\ ${ }^{1}$ Spectroscopie de l'Atmosphère, Service de Chimie Quantique et Photophysique, Université Libre de Bruxelles, \\ Brussels, Belgium \\ ${ }^{2}$ UPMC Univ. Paris 6, Université Versailles St.-Quentin, CNRS/INSU, LATMOS-IPSL, Paris, France \\ Correspondence to: L. Clarisse (lclariss@ulb.ac.be)
}

Received: 15 November 2011 - Published in Atmos. Meas. Tech. Discuss.: 7 December 2011

Revised: 23 February 2012 - Accepted: 6 March 2012 - Published: 13 March 2012

\begin{abstract}
Thermal infrared sounding of sulphur dioxide $\left(\mathrm{SO}_{2}\right)$ from space has gained appreciation as a valuable complement to ultraviolet sounding. There are several strong absorption bands of $\mathrm{SO}_{2}$ in the infrared, and atmospheric sounders, such as AIRS (Atmospheric Infrared Sounder), TES (Tropospheric Emission Spectrometer) and IASI (Infrared Atmospheric Sounding Interferometer) have the ability to globally monitor $\mathrm{SO}_{2}$ abundances. Most of the observed $\mathrm{SO}_{2}$ is found in volcanic plumes. In this paper we outline a novel algorithm for the sounding of $\mathrm{SO}_{2}$ above $\sim 5 \mathrm{~km}$ altitude using high resolution infrared sounders and apply it to measurements of IASI. The main features of the algorithm are a wide applicable total column range (over 4 orders of magnitude, from 0.5 to 5000 dobson units), a low theoretical uncertainty (3-5\%) and near real time applicability. We make an error analysis and demonstrate the algorithm on the recent eruptions of Sarychev, Kasatochi, Grimsvötn, Puyehue-Cordón Caulle and Nabro.
\end{abstract}

\section{Introduction}

Prodigious amounts of sulphur dioxide $\left(\mathrm{SO}_{2}\right)$ are released every year in the atmosphere. Anthropogenic emissions, mostly coming from combustion of sulphur-rich biomass such as coal and petroleum, add up to $50-65 \mathrm{Tg} \mathrm{S} \mathrm{yr}^{-1}$ (Smith et al., 2011; Lee et al., 2011). Volcanoes are the largest natural source of sulphur dioxide and account for 7.5-10.5 $\mathrm{Tg} \mathrm{S} \mathrm{yr}^{-1}$ on average (Andres and Kasgnoc, 1998; Halmer et al., 2002). These emissions lead to acid deposition and can affect air quality and climate through the formation of sulfate aerosols (Longhurst et al., 1993; Chin and Jacob, 1996; Graf et al., 1997; Haywood and Boucher, 2000; Robock, 2000; Zhang et al., 2007). While in general only a fraction of the emissions makes it to the upper troposphere and lower stratosphere (UTLS), a large volcanic eruption reaching the UTLS can impact the climate significantly as the lifetime of sulfate aerosol is proportional to the injection altitude. Bottom up approaches are well suited to determine total emissions of anthropogenic $\mathrm{SO}_{2}$ and emissions of some degassing volcanoes, but quantifying UTLS $\mathrm{SO}_{2}$ emissions is best done directly via satellite measurements (Bluth et al., 1993). In this paper we detail a novel algorithm for calculating $\mathrm{SO}_{2}$ columns above the mid troposphere $(500 \mathrm{hPa})$ from infrared (IR) satellite measurements.

Apart from climatological relevance, measuring high altitude $\mathrm{SO}_{2}$ is also important for studying uplift of anthropogenic pollution (e.g. Clarisse et al., 2011b), for analyzing explosive volcanic eruptions (e.g. Carn and Prata, 2010), and, when data are available in near real time, for monitoring volcanic activity (e.g. Surono et al., 2012) and tracking of volcanic clouds for the mitigation of aviation hazards (Prata, 2008; Rix et al., 2009; Carn et al., 2009).

Since 1978, the Total Ozone Mapping Spectrometer (TOMS) (Krueger et al., 1995) and subsequent follow-up ozone monitoring instruments have been measuring $\mathrm{SO}_{2}$ through solar backscattered ultraviolet (BUV) measurements (see e.g. Yang et al., 2007, and references therein). BUV measurements have a good sensitivity to $\mathrm{SO}_{2}$, even in the lowest atmospheric layers. The record of IR sounding of $\mathrm{SO}_{2}$ also goes back to 1978 with the High-Resolution Infrared Sounder (HIRS/2) (Prata et al., 2003). One clear advantage of thermal infrared (TIR) instruments is that they can measure in the absence of sunlight (thus also at night and at high latitudes in the winter) and often have a higher spatial resolution. For an overview of satellite instruments capable of measuring $\mathrm{SO}_{2}$ and their characteristics and limitations, we refer to Thomas and Watson (2010). Here we give a short 
overview of TIR sounding of $\mathrm{SO}_{2}$ without going into instrumental specifics.

Sulphur dioxide has three absorption bands in the mid infrared, see Fig. 1. The $v_{3}$ is by far the strongest band. Competing water vapor absorption limits its vertical sensitivity to $\mathrm{SO}_{2}$ above $3-5 \mathrm{~km}$, depending on the humidity profile and $\mathrm{SO}_{2}$ abundance. Higher altitude $\mathrm{SO}_{2}$ is also affected, directly, by water vapor in and above the $\mathrm{SO}_{2}$ layer, but also indirectly by variable radiation coming from below. The $v_{1}$ band is situated in an atmospheric window, and can penetrate the lower troposphere. While water vapor is not as important here, the $800-1200 \mathrm{~cm}^{-1}$ region is very sensitive to the surface temperature, surface emissivity and volcanic ash (Clarisse et al., 2010a,b), and for young volcanic plumes from explosive eruptions, $\mathrm{SO}_{2}$ and ash often need to be retrieved simultaneously. The combination band $v_{1}+v_{3}$ can only be used when there is reflected solar light. It is weak, but has been applied for the study of major volcanic eruptions as an alternative to a saturating $v_{3}$ band (Karagulian et al., 2010; Prata et al., 2010). Note that all TIR measurements require thermal contrast between the $\mathrm{SO}_{2}$ plume and the underlying source of radiation.

Broadband instruments typically have a handful of channels (each covering $50-100 \mathrm{~cm}^{-1}$ ) which can be used to retrieve $\mathrm{SO}_{2}$. Most retrieval algorithms are based on approximating the $\mathrm{SO}_{2}$ affected bands from the other bands assuming the absence of $\mathrm{SO}_{2}$. The difference between these reconstructed background radiances and the observed radiances can then be used to infer abundances. In the case of the $v_{1}$ band this can be done by first estimating the surface temperature (Realmuto et al., 1994, 1997) or by assuming a linear correlation with another band (Prata and Kerkmann, 2007). For the $v_{3}$ band it has been shown that it is possible to estimate the relevant unperturbed band radiance from a linear interpolation of two other bands (Prata et al., 2003; Doutriaux-Boucher and Dubuisson, 2008). Other schemes rely on the use of a large series of simulated radiances (see e.g. Corradini et al., 2010). For retrievals using the $v_{1}$ band, explicit (Corradini et al., 2009) or implicit (Campion et al., 2010) corrections for aerosols can be made.

Retrievals using high spectral resolution instruments typically use (optimal) least square procedures (Carn et al., 2005; Prata and Bernardo, 2007; Clerbaux et al., 2008; Clarisse et al., 2008), preceded by a $\mathrm{SO}_{2}$ detection routine. These are time consuming, but have the advantage of fully exploiting the spectral resolution by simultaneously retrieving competing species (e.g. $\mathrm{H}_{2} \mathrm{O}$ ) and potentially extracting plume altitude information. It was shown (Karagulian et al., 2010; Haywood et al., 2010) that for the $\nu_{3}$ band it often suffices to perform optimal estimation on a selected number of pixels and exploit the empirical correlation between these retrieved total columns and brightness temperature differences. It is this scheme we generalize and put on a more solid theoretical footing. Instead of relying on optimal estimation retrievals, however, we use elementary radiative transfer and a large lookup table. Our algorithm is akin to some of the methods applied for broadband sensors. The advantage, however, is that we can select specific channels, making the algorithm simpler and less sensitive to changes of other atmospheric variables (water vapour, clouds).

We outline the algorithm for observations of the high resolution infrared sounder IASI (Clerbaux et al., 2009), but it can easily be transferred to other high resolution sounders. Instrumental specifics of the IASI instrument are a continuous spectral coverage between 645 and $2760 \mathrm{~cm}^{-1}$, a spectral resolution of $0.5 \mathrm{~cm}^{-1}$ (which is apodized at $0.25 \mathrm{~cm}^{-1}$ ) and a noise equivalent delta temperature at $280 \mathrm{~K}$ around $0.05 \mathrm{~K}$ for the $\nu_{3}$ band and $0.12 \mathrm{~K}$ for the $\nu_{1}$ band. It has a global coverage twice a day with a footprint ranging from circular (12 km diameter at nadir) to elliptical (up to 20 by $39 \mathrm{~km}$ at the end of the swath) and a mean local equatorial overpass time at 09:30 LT and 21:30 LT.

In the next section we outline the theoretical basis of the algorithm. In Sect. 3 we give an overview of the most important sources in the error budget. Examples are presented in Sect. 4 and we conclude in Sect. 5.

\section{The algorithm}

In what follows, we assume an atmosphere with a $\mathrm{SO}_{2}$ cloud present at a given altitude. We adopt the notations from Watson et al. (2004). When the plume is at sufficient altitude (where the absorption of other species can be ignored) the measured radiance $L_{\mathrm{S}}$ at a wavenumber $v$ (and corresponding measured brightness temperature at the sensor $T_{\mathrm{S}}$ ) can be approximated as

$L_{\mathrm{s}}(v)=L_{\mathrm{ucb}}(v) t_{\mathrm{c}}+L_{\mathrm{c}}(v)\left(1-t_{\mathrm{c}}\right)$,

with $L_{\mathrm{c}}(v)=B\left(v, T_{\mathrm{c}}\right)$ the ambient radiance coming from the cloud at temperature $T_{\mathrm{c}}$ and specified by Planck's law, $L_{\text {ucb }}(v)$ the upwelling radiance at the cloud base and $t_{\mathrm{c}}$ the transmission of the cloud, given by the Bouguer-LambertBeer law

$t_{\mathrm{c}}=e^{-c u}$,

with $c$ an absorption coefficient dependent on pressure and temperature and $u$ the column abundance. While Eq. (1) is valid under the mentioned assumptions, a subtlety arises when applying it to real measurements. Real radiance measurements are always integrated (convolved) over a wavenumber interval and are altered by the instrumental line shape. To check to what extent Eq. (1) holds at the level of finite microwindows (here IASI channels), we have simulated the radiative transfer of a standard atmosphere and introduced a $\mathrm{SO}_{2}$ layer at a fixed altitude, but with varying abundances. The results are shown in Fig. 2 in brightness temperature space at wavenumber $v=1371.75 \mathrm{~cm}^{-1}$. The simulations are shown as black squares and the best fit with Eq. (1) (best choice of the absorption coefficient $c$ ) is shown 


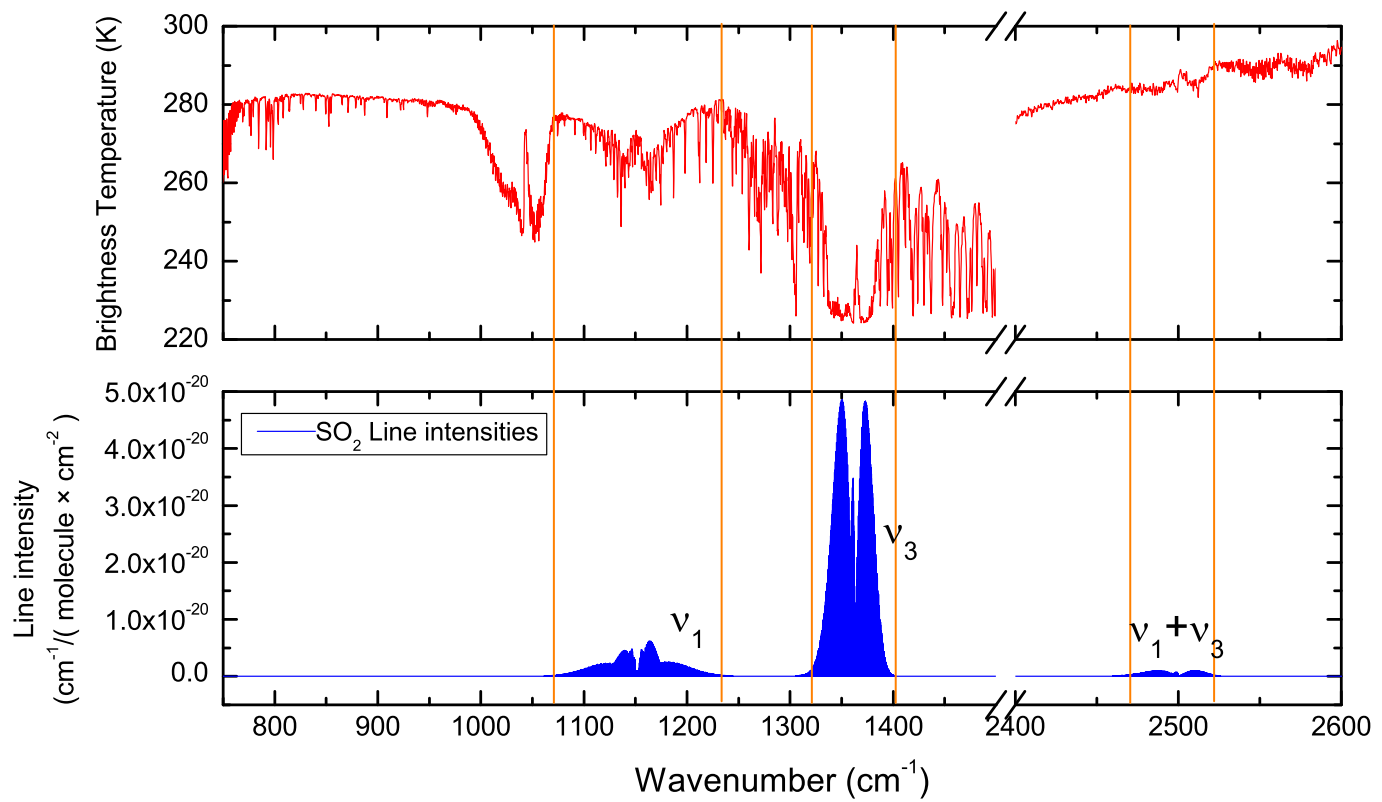

Fig. 1. Top panel: example IASI spectrum measured over the plume of the August 2008 eruption of Kasatochi. Bottom panel: line positions and intensities of $\mathrm{SO}_{2}$ from HITRAN (see Rothman et al., 2009, and references therein). Band centers and integrated band intensities of $\mathrm{SO}_{2}$ are (see Flaud et al., 2009, and references therein): the $v_{1}$ symmetric stretch $\left(\sim 1152 \mathrm{~cm}^{-1}=8.7 \mu \mathrm{m}\right.$ at $0.35 \times 10^{-17} \mathrm{~cm}^{-1} /\left(\right.$ molecule $\left.\left.\mathrm{cm}^{-2}\right)\right)$, the $\nu_{3}$ asymmetric stretch $\left(\sim 1362 \mathrm{~cm}^{-1}=7.3 \mu \mathrm{m}\right.$ at $\left.2.72 \times 10^{-17} \mathrm{~cm}^{-1} /\left(\mathrm{molecule} \mathrm{cm}^{-2}\right)\right)$ and the $v_{1}+v_{3}$ combination band $\left(\sim 2500 \mathrm{~cm}^{-1}=4 \mu \mathrm{m}\right.$ at $0.054 \times 10^{-17} \mathrm{~cm}^{-1} /\left(\right.$ molecule $\left.\left.\mathrm{cm}^{-2}\right)\right)$.
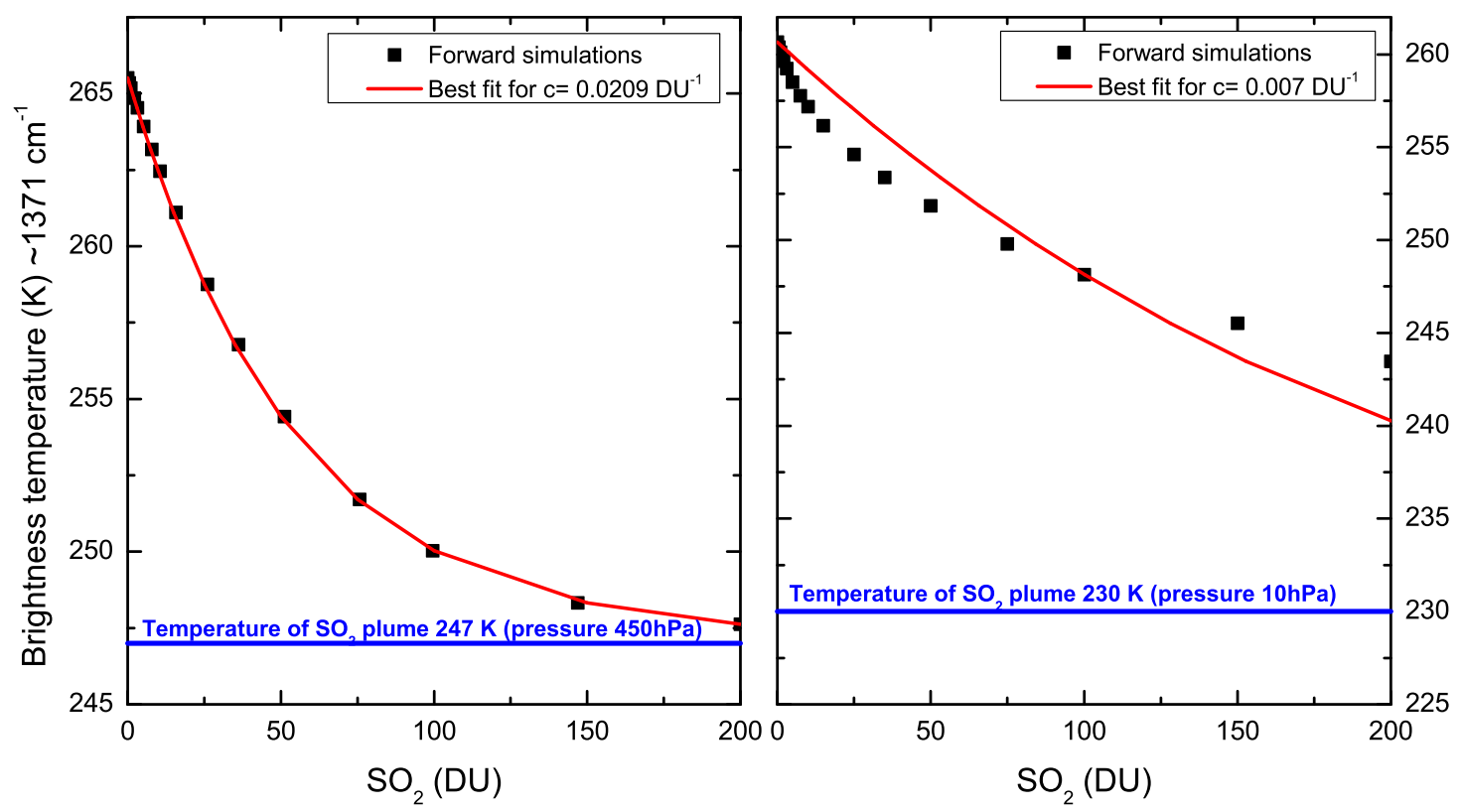

Fig. 2. Brightness temperature at $1371.75 \mathrm{~cm}^{-1}$ as a function of $\mathrm{SO}_{2}$ mass loading for a low (left, plume at $247 \mathrm{~K}$ and $450 \mathrm{hPa} \sim 5 \mathrm{~km}$ ) and high (right, plume at $230 \mathrm{~K}$ and $10 \mathrm{hPa} \sim 25 \mathrm{~km}$ ) altitude plume. The colored black squares were calculated from simulated IASI spectra, while the red full line is a best fit of these simulations with Eq. (1). 
in red. For a plume at high pressure (left panel, $450 \mathrm{hPa}$ ), an almost perfect fit can be obtained. The asymptotic behavior for increasingly large abundances can also be observed $\left(L_{\mathrm{s}}\right.$ $(v) \rightarrow B\left(v, T_{\mathrm{c}}\right)$ or $\left.T_{\mathrm{s}} \rightarrow T_{\mathrm{c}}\right)$. This saturation is slower for lower pressure (right panel, $10 \mathrm{hPa}$ ). At very low pressure, spectral lines saturate at a lower concentration at their line centers than their wings. In contrast, at a higher pressure, pressure broadening of the individual lines is important and will distribute absorption over a wider spectral range, resulting in a net larger absorption and thus a quicker saturation over the complete band when taking into account all spectral lines. For the low pressure test case, a good fit with Eq. (1) and a constant absorption coefficient $c$ is not possible. Because of the lower pressure broadening, the instrumental line shape and apodisation become relatively more important, and these effects are not taken into account in Eq. (1). One way to resolve this is to introduce an explicit column dependence in the coefficient $c$, so that $c=c(T, P, u)$. These coefficients can be estimated from forward simulations as outlined below.

To determine the $\mathrm{SO}_{2}$ abundance from Eq. (1), all that is left is to estimate $L_{\mathrm{ucb}}(v)$. This can be done from channels not affected by $\mathrm{SO}_{2}$, but for which the channel $v$ responds similarly to $\mathrm{H}_{2} \mathrm{O}$ and other atmospheric parameters than the channels sensitive to $\mathrm{SO}_{2}$. It is here easier to work in brightness temperature space, where Eq. (1) reads

$$
B\left(T_{\mathrm{s}}, v\right)=B\left(T_{\mathrm{ucb}}, v\right) t_{\mathrm{c}}+B\left(T_{\mathrm{c}}, v\right)\left(1-t_{\mathrm{c}}\right) .
$$

Now $T_{\text {ucb }}$ can be estimated from another channel $v^{\prime}$ when for background concentrations of $\mathrm{SO}_{2}$

$T_{\mathrm{S}}=B^{-1}\left(L_{\mathrm{s}}(v), v\right) \approx B^{-1}\left(L_{\mathrm{S}}\left(v^{\prime}\right), v^{\prime}\right)=T_{\text {ucb }}$.

The critical part is to choose these channels $v$ and $v^{\prime}$ to make this estimate as good as possible. We have used combinations of 4 channels: two to estimate $T_{\mathrm{s}}$, representing the absorption in the $v_{3}$ band and two reference channels to estimate $T_{\text {ucb. Table }} 1$ lists two sets of such parameters together with their bias and standard deviation (estimated from a full day of IASI measurements with no detectable volcanic $\mathrm{SO}_{2}$ ). Note that this doubling of channels allows to reduce the standard deviation significantly and also that the bias can be subtracted in the calculation of the brightness temperature difference. Figure 3 illustrates the sensitivity range of both sets for a plume at $150 \mathrm{hPa}$. The absorption channels in the $v_{3}$ band of the first set are chosen close to the region of maximum absorption, around $1371.75 \mathrm{~cm}^{-1}$. It is sensitive to mass loadings as low as $0.5 \mathrm{DU}$, but saturates at around 200 DU, above which differences in the observed channels become too small. The second set has its absorption channels further away from the band center, at $1385 \mathrm{~cm}^{-1}$. It has a lower sensitivity of about $10 \mathrm{DU}$, but can measure columns up to $5000 \mathrm{DU}$. The combined use of both sets therefore enables to retrieve columns of $\mathrm{SO}_{2}$ from about 0.5 to $5000 \mathrm{DU}$ at $150 \mathrm{hPa}$.

Equation (1) is only valid when no absorption above the $\mathrm{SO}_{2}$ plume takes place. Even at altitudes above $\sim 500 \mathrm{hPa}$

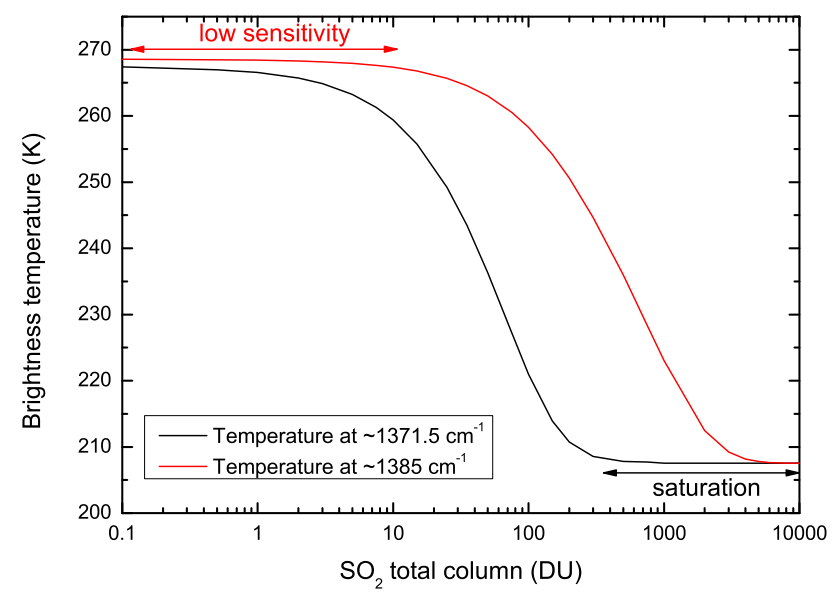

Fig. 3. Brightness temperature of the two sets of absorption channels (at $\sim 1371.5 \mathrm{~cm}^{-1}$ and at $\sim 1385 \mathrm{~cm}^{-1}$ ) as a function of $\mathrm{SO}_{2}$ abundance for a plume located at $150 \mathrm{hPa}$ and $207 \mathrm{~K}$.

altitude, some residual water absorption can still affect observed channels. Assuming that water vapour above is colder than the $\mathrm{SO}_{2}$ plume (so disregarding significant water vapor above lower stratospheric plumes), we have for a saturating cloud $T_{\mathrm{S}}<T_{\mathrm{c}}$. We therefore introduce a virtual cloud temperature $T_{\mathrm{c}}^{*}=T_{\mathrm{c}}-\left[\mathrm{H}_{2} \mathrm{O}\right] / 10^{21}$, with $\left[\mathrm{H}_{2} \mathrm{O}\right]$ the partial column of water (in molecules $\mathrm{cm}^{-2}$ ) above the $\mathrm{SO}_{2}$ layer . The factor $10^{21}$ was determined empirically, and while this is a first order correction, it is largely sufficient as we will see below.

To calculate the absorption coefficients $c(T, P, u)$ we have used representative atmospheric profiles (temperature, pressure, humidity and ozone) from the ECMWF 40-yr reanalysis, ERA-40 (Chevallier, 2001). The total set contains 13495 well sampled profiles. Pressure and temperature (PT) pairs between 5 and $30 \mathrm{~km}$ altitude are plotted in Fig. 4. The visible pressure bands are an artifact caused by the specific 60level coordinate system in the data set, and these disappear when working with the interpolated data. We have calculated $c(T, P, u)$ on a subgrid of this PT diagram, indicated by the black dots.

For each PT pair in the subgrid, we selected 10 atmospheres from ERA-40 with the closest match in the PT profile. A variable $\mathrm{SO}_{2}$ cloud (from 0 to $10000 \mathrm{DU}$ ) was then inserted at the altitude corresponding to the PT pair and the resulting IASI spectrum was simulated. Based on these simulations a best value for $c(T, P, u)$ was obtained from minimizing the relative error between the real and the calculated $\mathrm{SO}_{2}$ abundance. Each $c(T, P, u)$ is obtained from 10 independent simulations and determining the best value is therefore an over-constrained problem. The solution however is guaranteed not to be overly dependent on an individual atmosphere, and the average relative error is a good indication for the theoretical error (caused by the variability of other atmospheric parameters) which can be achieved with this algorithm. 
Table 1. Two sets of absorption and background channels used in the calculation of $\mathrm{SO}_{2}$ abundances. The mean and standard deviation of their brightness temperature differences were calculated on one day with no detectable quantities of $\mathrm{SO}_{2}$.

\begin{tabular}{ccccc}
\hline & $\nu_{3}$ Absorption channels & Background channels & Mean & Std \\
\hline Set 1 & $1371.50,1371.75 \mathrm{~cm}^{-1}$ & $1407.25,1408.75 \mathrm{~cm}^{-1}$ & $-0.05 \mathrm{~K}$ & $0.15 \mathrm{~K}$ \\
Set 2 & $1384.75,1385.00 \mathrm{~cm}^{-1}$ & $1407.50,1408.00 \mathrm{~cm}^{-1}$ & $0.05 \mathrm{~K}$ & $0.25 \mathrm{~K}$ \\
\hline
\end{tabular}

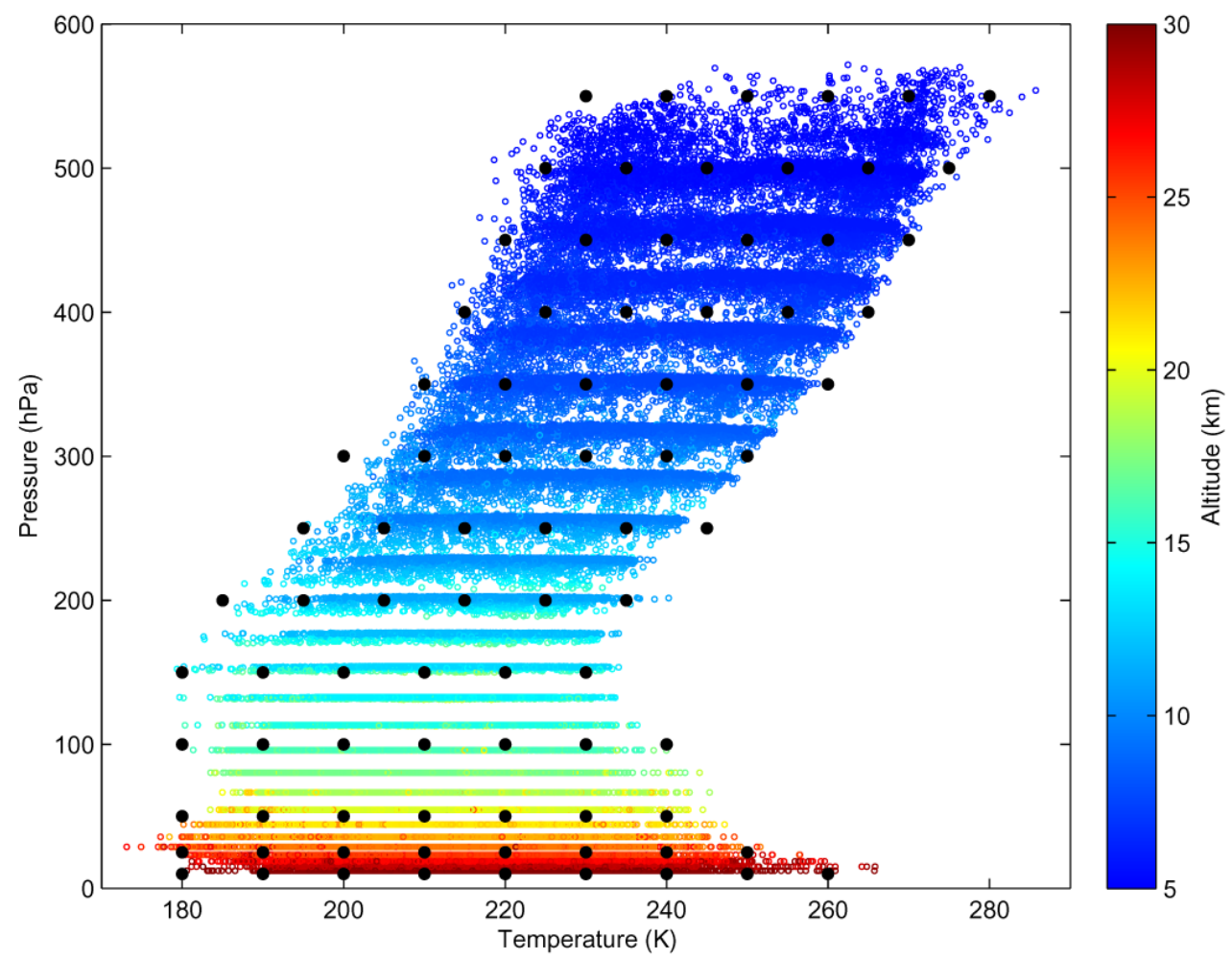

Fig. 4. Pressure and temperature correlations of the ERA-40 data set between 5 and $30 \mathrm{~km}$. The black dots are the PT pairs for which the lookup tables were built.

The top panel in Fig. 5 shows the absorption coefficients for the two sets of channels at 10 and $750 \mathrm{DU}$ respectively. For $4 \mathrm{PT}$ pairs, $T_{\text {ucb }}$ was very close or inferior to $T_{\mathrm{c}}$ for all 10 profiles. These sets of low thermal contrast or temperature inversion were excluded. These are situated at the very edge of the PT space and are uncommon. The bottom panel shows the mean relative error between the input $\mathrm{SO}_{2}$ abundance and the retrieved for the ten different profiles. Errors are less than $3 \%$ and $5 \%$ for the first and second set respectively, except again at some points at the edge of the PT space.

We end this section with a practical consideration, which is important in the implementation of the above retrieval algorithm. The use of $c(T, P, u)$ to calculate the column abundance $u$ is inherently a recursive problem. It is therefore necessary to start with a first guess $c(T, P)$ and iteratively calculate $u$ and $c(T, P, u)$ until convergence is achieved. We have verified numerically that this convergence is always achieved (due to the smooth and monotonous behavior of the $c$ coefficients). Also note that we find two estimates $u_{1}$ and $u_{2}$ for $u$, for each set of absorption and background channels. Theoretically, these two estimates should only agree when the assumed altitude corresponds to the real altitude (because the corresponding brightness temperature differences have a different pressure and temperature dependence). From looking at a few test cases, the two estimates generally agree well between $25 \mathrm{DU}$ and $75 \mathrm{DU}$ (with a standard deviation of around $10 \%$ ). On either side of this range, differences increase, with the $u_{1}$ estimate obviously superior for lower total column amounts and the $u_{2}$ estimate by construction superior for large column total amounts. When either $u_{1}$ or $u_{2}$ exceed $100 \mathrm{DU}$, we used the $u_{2}$ estimate, otherwise $u_{1}$ was used. Finally, the retrieval is also preceded by a detection criterion, here taken to be $T_{\mathrm{ucb}}-T_{\mathrm{S}}>0.4 \mathrm{~K}$. 

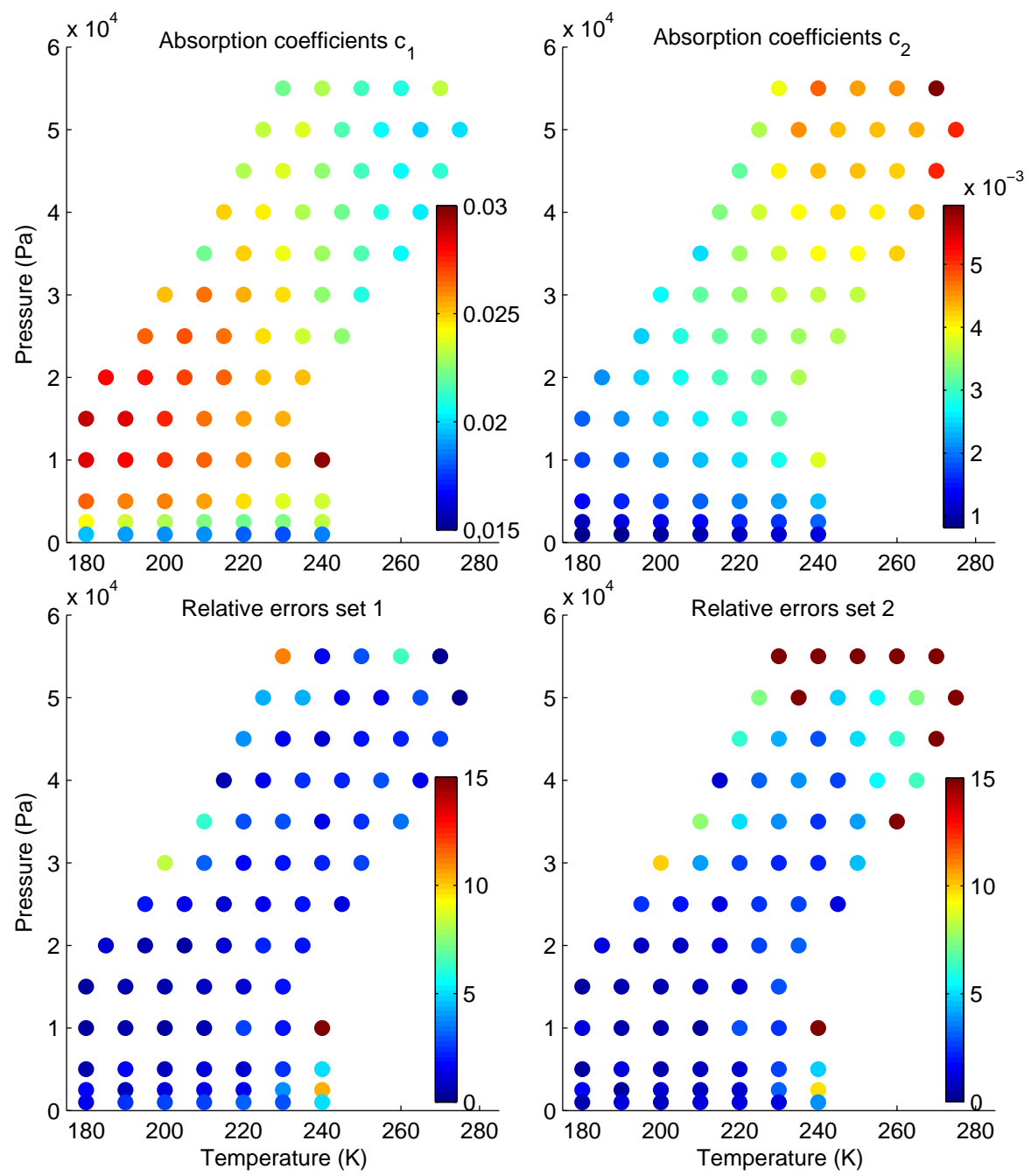

Fig. 5. Absorption coefficients for the two sets of IASI channels (top) and their corresponding average errors in percentage (bottom). Here the absorption coefficients and errors are shown for a $\mathrm{SO}_{2}$ cloud of $10 \mathrm{DU}$ (set 1) and $750 \mathrm{DU}$ (set 2) respectively.

\section{Sources of error}

A good description of typical sources of error can be found in Prata et al. (2003). Most of these are inherent to any retrieval which uses the $v_{3}$ band. There are broadly speaking five main sources of error. The first category is related to propagation of errors in the measurements, in our case in the measurements of $T_{\mathrm{S}}$ and $T_{\mathrm{ucb}}$. The second category includes errors related to the assumed or measured altitude or cloud temperature $T_{\mathrm{c}}$. A third source of errors becomes important when Eq. (1) is no longer a good approximation for the radiative transfer due to presence of aerosols above the $\mathrm{SO}_{2}$ layer. There is the modeling error related to Eq. (1), which was estimated above to be in the range $3-5 \%$, and finally there are errors related to spectroscopy and radiative transfer. In this section we will discuss the first three types of error.

\subsection{Measurements errors}

We call measurements errors any errors that affect the difference of $T_{\mathrm{S}}$ and $T_{\mathrm{ucb}}$ beyond the contribution of $\mathrm{SO}_{2}$. This includes the instrumental noise, but also contributions from the fact that the background channels are only a best-effort estimate of the absorption channels in the absence of $\mathrm{SO}_{2}$. Following Table 1 we estimate the error to be of the order $0.15 \mathrm{~K}$ and $0.25 \mathrm{~K}$ for the first and second set of channels. From Fig. 3 it is easily seen that the influence of these errors will be largest for very thin or very thick $\mathrm{SO}_{2}$ clouds. For very thin clouds the contribution of $\mathrm{SO}_{2}$ on $T_{\mathrm{S}}$ will be of the same order of magnitude as the measurement error and hence relatively important. For very thick clouds, we are close to saturation regime and a small error on the observed temperatures will lead to large differences in the $\mathrm{SO}_{2}$ estimates. As an example of how this type of error translates in errors on the abundance, an error of $0.15 \mathrm{~K}$ and $0.25 \mathrm{~K}$ was introduced 


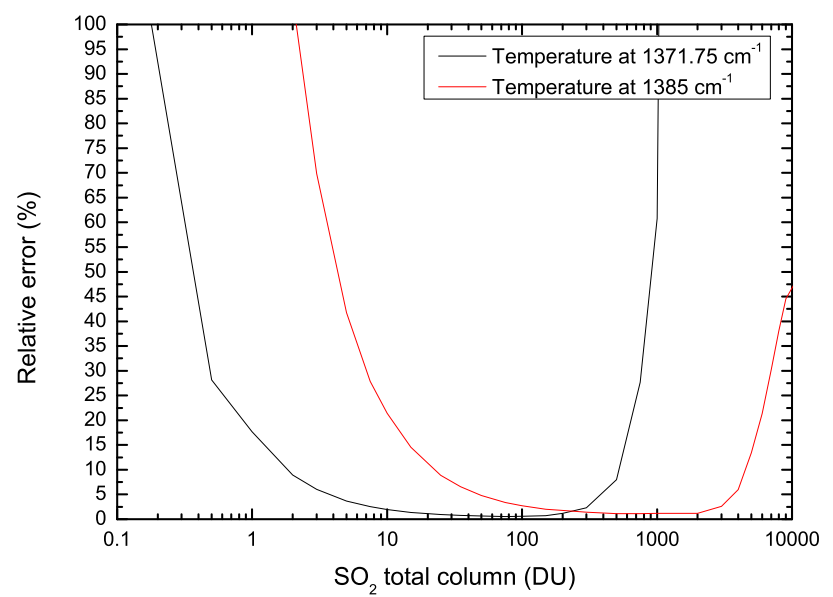

Fig. 6. Illustration of the measurement error. Relative errors in the retrieved abundances, made from introducing $0.15 \mathrm{~K}$ and $0.25 \mathrm{~K}$ error in the data of Fig. 3.

in the data of Fig. 3 and the relative differences are plotted in Fig. 6. It illustrates the increase of errors near the extremes. The errors between $0.5 \mathrm{DU}$ and $5000 \mathrm{DU}$ are in this example below $30 \%$ (and below $6 \%$ for loadings above $3 \mathrm{DU}$ ). It should be stressed though that this type of error is a random error and averages out when calculating the total mass of plumes much larger than the footprint of the instrument.

Related to this, there is the situation where the $\mathrm{SO}_{2}$ cloud at $T_{\mathrm{c}}$ has little or no thermal contrast with the radiation from

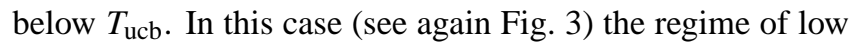
sensitivity and the regime of saturation overlap and errors are naturally very large. This dependence on thermal contrast is inherent to IR sounding.

\subsection{Altitude}

As the present algorithm does not retrieve altitude, a cloud altitude (and therefore pressure and temperature) must be assumed. This affects the estimated loading through the assumed water vapour absorption above the plume, $c(T, P, u)$ and $T_{\mathrm{c}}$. The latter is the most important, especially close to saturation or when considering large temperature differences. To assess their combined effect it is best to look at some examples. Figure 7 is a plot of retrieved total masses (as a percentage of the maximum measured total mass for a given altitude) for different eruptive plumes (young and aged) as a function of the assumed altitude.

To understand the effect of the assumed altitude it is useful to look at the thermal contrast between the cloud and the background $\left(T_{\mathrm{ucb}}-T_{\mathrm{c}}\right)$. Water vapour is the main source of the upwelling radiance in the vicinity of the $\nu_{3}$ band and $T_{\text {ucb }}$ therefore corresponds to an altitude of $3-6 \mathrm{~km}$. At cloud altitudes between 5 and $7 \mathrm{~km}$ the temperature contrast is low and maximum amounts of $\mathrm{SO}_{2}$ are required to produce the observed absorption. For clouds at the tropopause

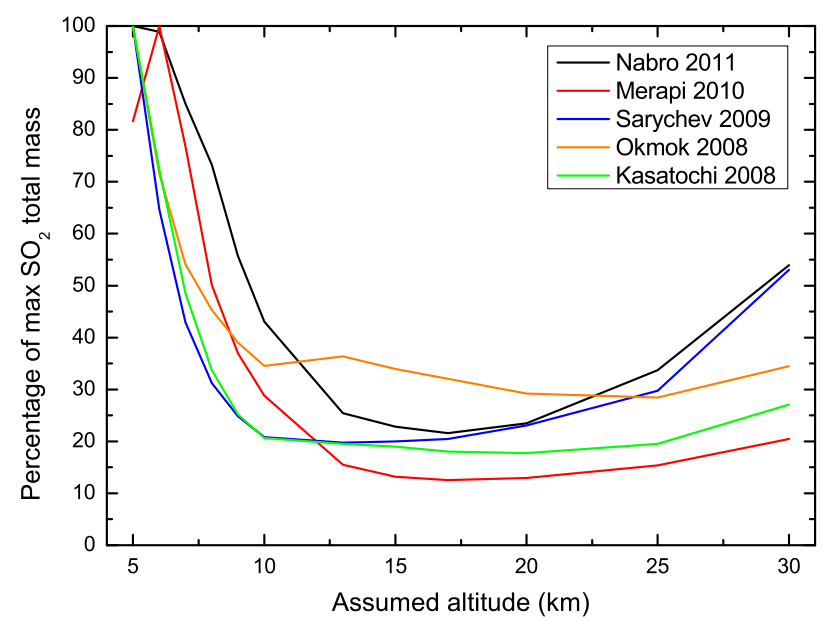

Fig. 7. Effect of the assumed altitude on retrieved abundances; illustrated for different eruptions.

the temperature contrast is highest and the minimum amount of $\mathrm{SO}_{2}$ is required to account for the observed absorption. For instance the Merapi (Java/Indonesia) and the Nabro (Eritrea) plumes have their minimum retrieved mass at a higher altitude $(17 \mathrm{~km})$ than e.g. Sarychev (Kuril Islands, Russia) or Kasatochi (Aleutian Islands, Alaska) plumes, which have their minimum at $10-12 \mathrm{~km}$. In the stratosphere the $\mathrm{SO}_{2}$ retrievals increase as $T_{\mathrm{c}}$ approaches $T_{\mathrm{ucb}}$, with the rate of increase controlled by the stratospheric temperature gradient. As can be seen from Fig. 7, the effect of altitude is generally within $10-20 \%$ between 10 and $20 \mathrm{~km}$. For low altitude plumes, the assumed altitude is more critical with differences up to $500 \%$ between a plume at 5 and $10 \mathrm{~km}$ due to the steep temperature gradient in the troposphere.

\subsection{Aerosols}

Large eruption plumes contain typically a large amount of various particles (ash, ice, sulfate aerosols and aggregates). All these absorb and scatter IR radiation. The wavenumber dependence is most pronounced for ash and ice as illustrated in Fig. 8 for the 2008 Kasatochi eruption (ash) and 2011 Nabro eruption (ice). Extinction of IR radiation by ash is strongest in the $800-1200 \mathrm{~cm}^{-1}$ range (see also Clarisse et al., 2010b), but almost uniform throughout the $\nu_{3}$ band of $\mathrm{SO}_{2}$. Note that the specific extinction depends on the total ash loading but also on the particle size distribution and the mineral composition. Ice particles have their largest extinction feature in the $800-1000 \mathrm{~cm}^{-1}$ range (see also Clarisse et al., 2008). The retrieval algorithm is not sensitive to what happens below the $\mathrm{SO}_{2}$ cloud as long as the radiation coming from below has sufficient thermal contrast with the $\mathrm{SO}_{2}$ plume and as long as the radiation at background and absorption channels extinguishes uniformly. Low-altitude aerosol layers of low-to-medium optical thickness which are located 

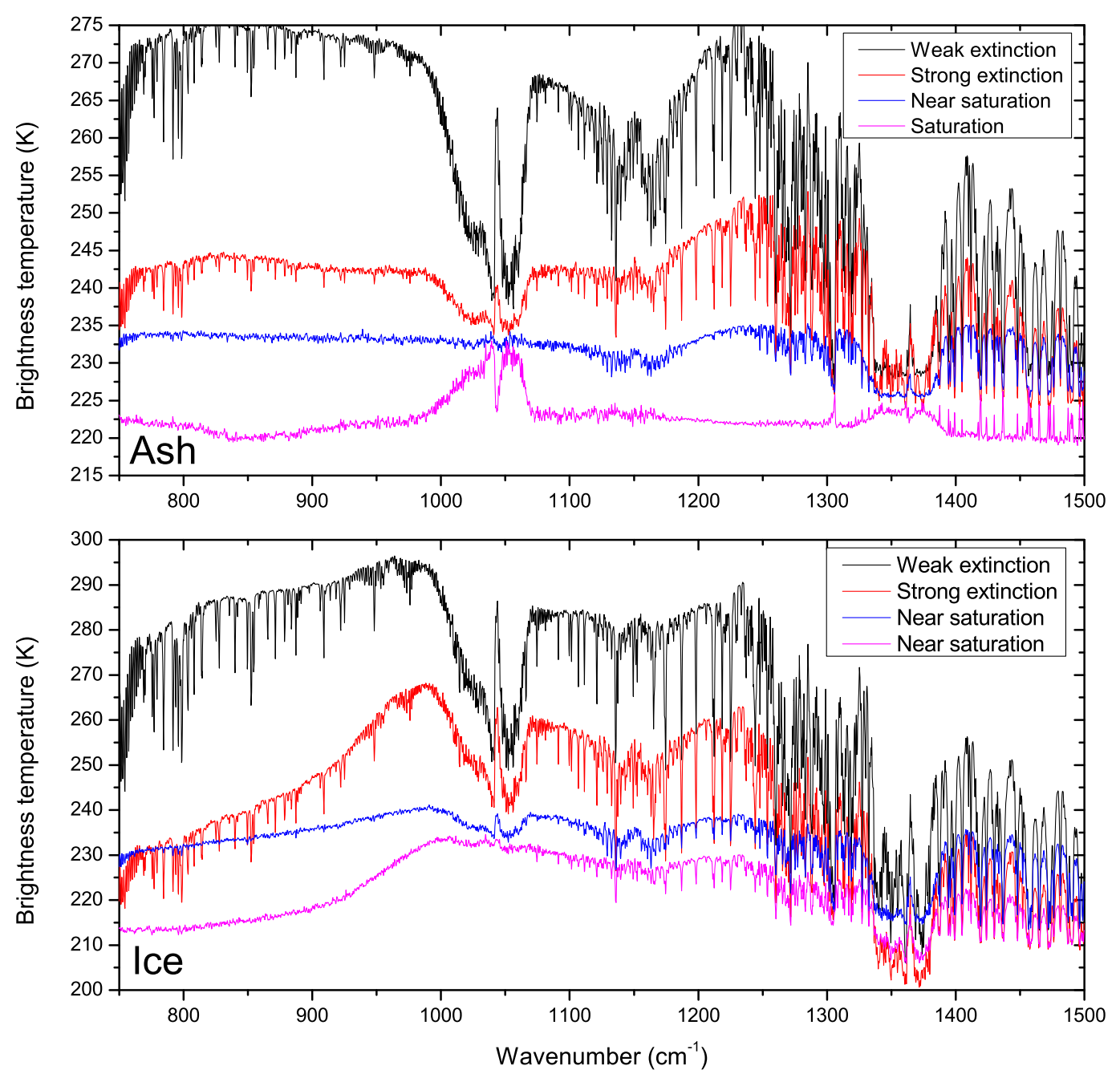

Fig. 8. Observed IASI spectra from the 2008 Kasatochi (top) and 2011 Nabro eruptions (bottom) illustrating the effect of volcanic aerosol (ash and ice). Different degrees of aerosol extinction demonstrate the damping of the $\mathrm{SO}_{2}$ signature. Note that some of the differences are also due to the different total column of water vapour.

well below the $\mathrm{SO}_{2}$ layer have therefore limited or no impact on our retrieval. Opaque aerosol layers just below the $\mathrm{SO}_{2}$ plume impede the sensitivity of the algorithm as is apparent when comparing the black and the blue spectra in the top panel of Fig. 8.

Aerosols above or at the same altitude as $\mathrm{SO}_{2}$ will have an impact on the retrieved abundance. As a test case, we have simulated the radiative transfer (following the methods described in Clarisse et al., 2010a) of a thick aerosol layer located below, above and in a $25 \mathrm{DU}$ upper tropospheric $\mathrm{SO}_{2}$ plume. The aerosol abundance was in the three cases chosen as to cause a drop of $20 \mathrm{~K}$ in the spectrum at $\sim 1362 \mathrm{~cm}^{-1}$. As expected and explained above, aerosol below the $\mathrm{SO}_{2}$ layer had limited impact $(2 \%)$ on the retrieved abundance. Ash in the $\mathrm{SO}_{2}$ layer caused a $20 \%$ overestimation, while aerosol above gave rise to a $45 \%$ overestimation. It is clear that the effect of aerosol depends very much on the specific aerosol loading and its altitude, and while our tests point to an overestimation of the $\mathrm{SO}_{2}$ loading, pixels with completely opaque ash in or above the $\mathrm{SO}_{2}$ layer will go undetected and this will lead to an underestimation of the total measured $\mathrm{SO}_{2}$ mass. An example of such a spectrum is shown in pink in the top of Fig. 8. A little $\mathrm{SO}_{2}$ can be detected at $\sim 225 \mathrm{~K}$ above the ash cloud at $\sim 220 \mathrm{~K}$, but everything below the ash cloud is not measurable.

Note finally that for fresh plumes, it is not uncommon for a portion of the erupted $\mathrm{SO}_{2}$ to be sequestered on ice, only to be later released in the volcanic cloud by sublimation (Rose et al., 2004). This could account for some of the increases in $\mathrm{SO}_{2}$ total mass timeseries observed in ice rich volcanic plumes (Krueger et al., 2008; Clarisse et al., 2008). 


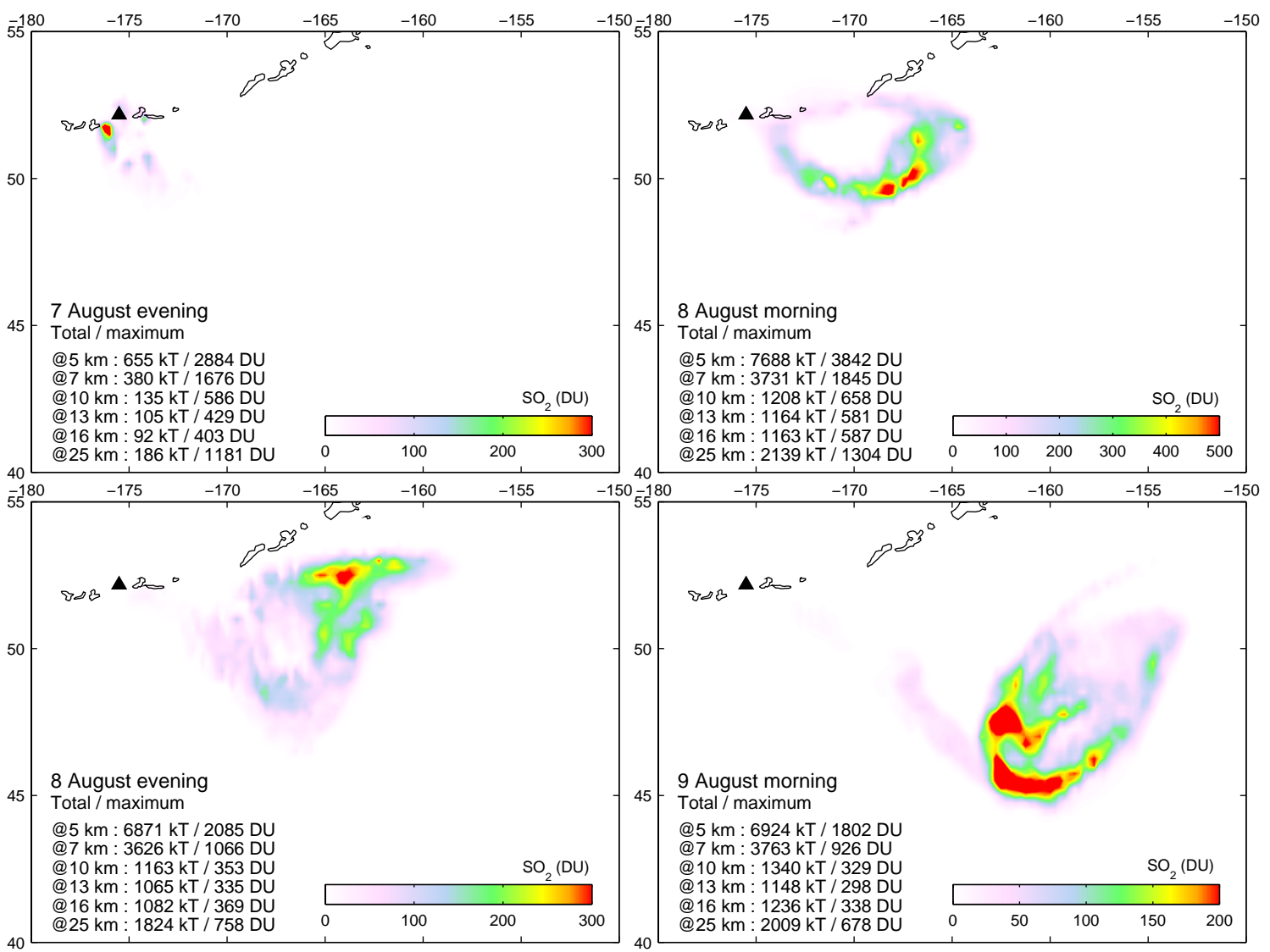

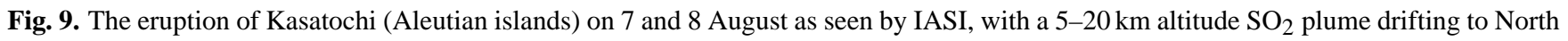
America. For the displayed columns an altitude of $10 \mathrm{~km}$ was assumed.

\section{Examples}

\subsection{Kasatochi - large columns}

Kasatochi volcano (part of the Aleutian Islands) erupted on 7 and 8 August 2008 five times (Waythomas et al., 2010) and ejected the largest amount of $\mathrm{SO}_{2}$ in the UTLS since the eruption of Cerro Hudson in 1991 (Krotkov et al., 2010). There are several aspects which complicate the $\mathrm{SO}_{2}$ retrieval. The five eruptions occurred in quick succession, and these were different in nature (phreatomagmatic and magmatic Waythomas et al., 2010) and altitude (5-20 km Kristiansen et al., 2010). The resulting plume was therefore highly heterogeneous in $\mathrm{SO}_{2}, \mathrm{H}_{2} \mathrm{~S}$ (Clarisse et al., 2011a), $\mathrm{H}_{2} \mathrm{O}$, ash (Corradini et al., 2010) and ice content and likely multilayered within a typical operational satellite's footprint $(>10 \mathrm{~km}$ diameter).

In terms of total ejected $\mathrm{SO}_{2}$ mass, estimates from satellites vary widely, from 1 to $3 \mathrm{Tg}$, in part due to the fact that most retrievals are based on a single cloud altitude. Estimates in the UV are $2.5 \mathrm{Tg}$ (Richter et al., 2009) from GOME2 (Global Ozone Monitoring Experiment-2) and 1.4 to $2.2 \mathrm{Tg}$ (Kristiansen et al., 2010; Krotkov et al., 2010) from OMI (Ozone Monitoring Instrument). In the IR estimates are 1.2 to $1.4 \mathrm{Tg}$ (Prata et al., 2010) from AIRS (Atmospheric Infrared Sounder), 1.7 Tg (Karagulian et al., 2010) from IASI and 0.94 to $2.65 \mathrm{Tg}$ (Corradini et al., 2010) from MODIS (Moderate Resolution Imaging Spectroradiometer). The main difficulty in comparing the respective retrievals is understanding the impact of the different assumed or calculated heights coupled with the different responses in the IR/UV absorption bands. Also important are the different strategies applied to cope with non-linear effects associated with very large columns as also reflected in the large variance in reported maximum columns, ranging from 100 to 700 DU: OMI 280 DU (Kristiansen et al., 2010), GOME2 100 DU (operational retrieval)-700 DU (Richter et al., 2009; Bobrowski et al., 2010) and IASI 300 DU (Karagulian et al., 2010).

Retrieval results using the new algorithm are shown in Fig. 9 for the first 4 IASI overpasses (the first overpass on 7 August happened after 3 of the 5 explosive events). In terms of maximum columns, the first overpass on the 8th measured columns in excess of $500 \mathrm{DU}$ (depending on the 


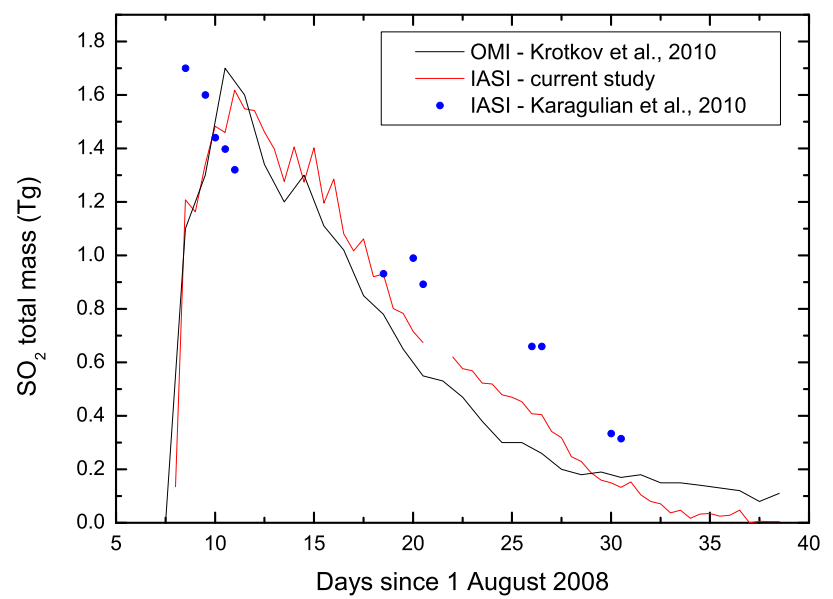

Fig. 10. Time series of $\mathrm{SO}_{2}$ measured with IASI: original study (Karagulian et al., 2010) in blue, current reanalysis in red and OMI (Krotkov et al., 2010) in black.

injection altitude). This is higher than any other retrieval reported using $\nu_{3}$ measurements, and of the same order as the maximum columns measured by GOME2 and shows the ability of our retrieval algorithm to deal efficiently with band saturation. Retrieved total masses vary from $3.7 \mathrm{Tg}(7 \mathrm{~km})$ over $1.3 \mathrm{Tg}(10-13 \mathrm{~km})$ to $2 \mathrm{Tg}(25 \mathrm{~km})$. As the plume was spread over altitudes ranging from 5 to $20 \mathrm{~km}$, this is again consistent with data from other sounders.

The retrieved total mass at $10 \mathrm{~km}$ (Krotkov et al., 2010; Karagulian et al., 2010) as a function of date is displayed in Fig. 10. We find that the retrieved values increase after the 9th to about $1.6 \mathrm{Tg}$ on the 11 August. As the presented algorithm is able to retrieve very large $\mathrm{SO}_{2}$ columns, we do not except saturation problems to be an issue. However, we made the assumption that the plume is concentrated at a single fixed altitude and so one possible reason for this posteruptive increase of the total mass is that part of the plume was vertically stratified, with the $\nu_{3}$ band mostly sensitive to the upper part (Corradini et al., 2010; Krotkov et al., 2010). By the 11th vertical wind shear probably dispersed the multilayered cloud sufficiently for it to be exposed completely.

For the overall time-series we find substantial differences (up to $50 \%$ ) with an earlier IASI analysis (Karagulian et al., 2010) which used the $v_{1}+v_{3}$ combination band for the retrievals of the plume on the 8th, 9th and 10th. This analysis did not exhibit an increase in retrieved total masses after the 8th (likely due to the weaker altitude/temperature dependency of the retrievals). However, a remarkable discrepancy of this earlier analysis with OMI retrievals was found for retrievals of the aged plume, with differences over $100 \%$ and leading to factor two in the estimated $e$-folding lifetime of $\mathrm{SO}_{2}$. In the present study measurements of IASI are compatible with the OMI retrievals (Krotkov et al., 2010), and the timeseries clearly fits the expected exponential decay better than the earlier analysis.

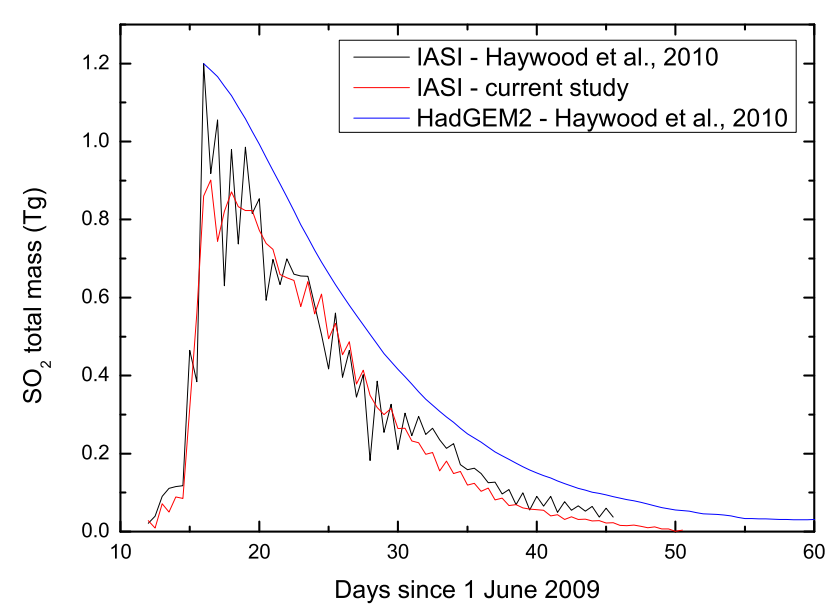

Fig. 11. Time series of $\mathrm{SO}_{2}$ measured with IASI: original study (Haywood et al., 2010) in black, current reanalysis in red and HadGEM2 model in blue.

\subsection{Sarychev - aging plume}

Another large eruption took place in 2009, namely Sarychev Peak (Kuril Islands, Russia) on 11-16 June (Matoza et al., 2011; Rybin et al., 2011; Haywood et al., 2010). There were several explosive events, but the majority of the high altitude $\mathrm{SO}_{2}$ was injected on 15 and 16 June at an altitude of 10 $16 \mathrm{~km}$. An earlier study (Haywood et al., 2010) using IASI data estimated the sulphur dioxide emissions for those two days to be of the order of $1.2 \pm 0.2 \mathrm{Tg}$ and this figure is commensurate with OMI measurements (Carn and Lopez, 2011). Like the Kasatochi eruption, the eruption of Sarychev peak presented a nice validation opportunity for modeling and measuring lower stratospheric injections of $\mathrm{SO}_{2}$ and gradual oxidation to sulfate (Haywood et al., 2010; Kravitz et al., 2011; Vernier et al., 2011).

Figure 11 shows the measured total mass in the Northern Hemisphere at $13 \mathrm{~km}$ (the total mass does not vary a lot for height assumptions between 10 and $16 \mathrm{~km}$ ) as a function of time in June 2009. The difference with the previous timeseries (shown in black and reported in Haywood et al., 2010) is minimal, except for the maximum retrieved value, which is now determined at $0.9 \mathrm{Tg}$. The current reanlysis is likely to be more accurate, given the fact that the original retrieved mass was quite noisy for the first week after the eruption (with differences up to $100 \%$ for consecutive overpasses). The current retrieval gives a very smooth timeseries. Note also that for the 2009 Sarychev eruption as a whole, the total released $\mathrm{SO}_{2}$ is likely higher then $0.9 \mathrm{Tg}$ as prior to $15 \mathrm{June}$ there were several smaller eruptions. 


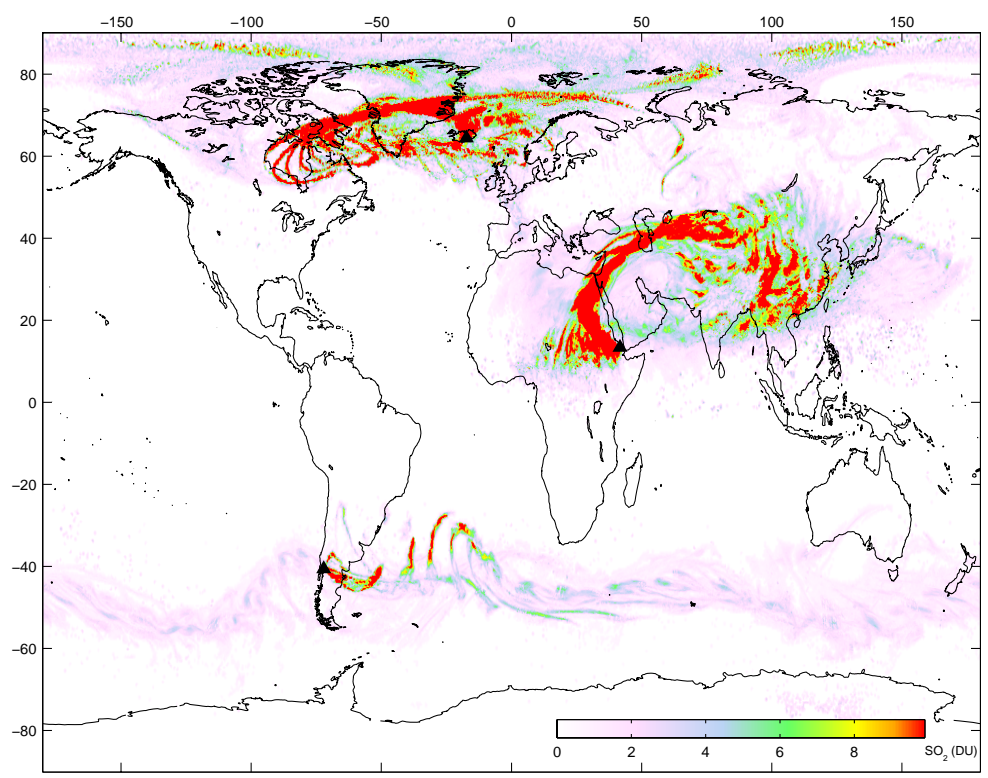

Fig. 12. Composite image of maximum observed $\mathrm{SO}_{2}$ columns for the period 20 May to 30 June 2011 . The value for each grid cell equals the maximum observed $\mathrm{SO}_{2}$ columns in that grid cell for the given time period during which three major volcanic eruptions took place. Grimsvötn $\left(-17.33^{\circ}, 64.42^{\circ}\right)$ erupted first on 21 May, then Puyehue-Cordón Caulle $\left(-40.59^{\circ},-72.12^{\circ}\right)$ on 3 June and finally Nabro $\left(13.37^{\circ}, 41.70^{\circ}\right)$ on 12 June. A plume altitude of $10 \mathrm{~km}$ was assumed.
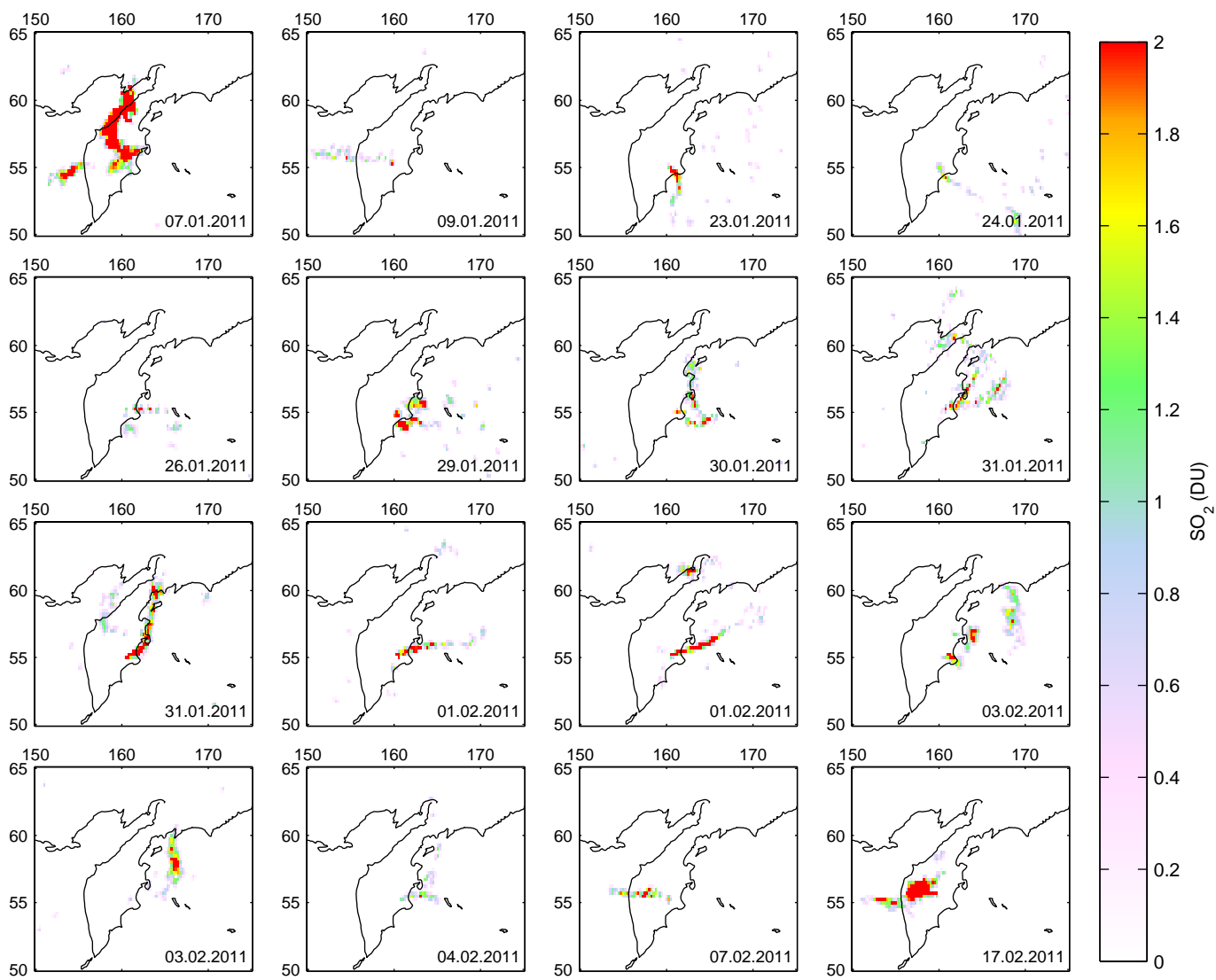

Fig. 13. Snapshots of volcanic $\mathrm{SO}_{2}$ plumes detected in the first part of 2011 over the Kamchatka Peninsula. 


\subsection{Grimsvötn, Puyehue-Cordón Caulle, Nabro - global retrievals}

In May and June 2011, three volcanoes erupted, each releasing large amounts of $\mathrm{SO}_{2}$ (Fig. 12). Near real time retrieval using the outlined algorithm illustrates its operational usefulness and robustness for a variety of very different atmospheric conditions and eruptive plumes. The retrieved total masses agree well with those retrieved from other sensors (AIRS and OMI) as reported on various forums and news sites. A full analysis taking into account precise altitude estimates is out of the scope of this paper and we report total masses here assuming an altitude of $10 \mathrm{~km}$.

Grimsvötn (Iceland) erupted first on 21 May, with about $350-400 \mathrm{kT}$ of $\mathrm{SO}_{2}$. Last traces of the initial plume were observed until the 15 June. $\mathrm{SO}_{2}$ from Puyehue-Cordón Caulle (Chile) was detected first on 5 June; and a fast westerly jet stream carried the plume of about $250 \mathrm{kT} \mathrm{SO}_{2}$ round the world in 9-10 days. The third eruption was the one of the volcano Nabro (Eritrea), which was prior to this event believed to be totally extinct and is not monitored so actively as other volcanoes. First $\mathrm{SO}_{2}$ was measured on 12 June and continued emissions were observed in the days and weeks which followed. Total masses of the order $1.5 \mathrm{Tg}$ were measured. Water and ice rich plumes and low altitude filaments hampered retrieval on several occasions, and we therefore believe this to be a lower bound. By the end of June all traces of Nabro plumes disappeared, which indicates a shorter lifetime of $\mathrm{SO}_{2}$ compared to Kasatochi or Sarychev. This is possibly due larger $\mathrm{H}_{2} \mathrm{O}$ and $\mathrm{OH}$ concentrations at tropical latitudes.

Apart from large volcanic eruptions, IASI regularly picks up smaller puffs from world's most active volcanoes such as Etna. As an example, Fig. 13 shows some snapshots of volcanic plumes detected in the first part of 2011 over the Kamchatka Peninsula (originating from volcanoes such as Bezymianny, Kizimen, Karymsky, Kliuchevskoi and Shiveluch).

\section{Conclusions}

In this paper we have presented an algorithm for retrieving $\mathrm{SO}_{2}$ abundances from IASI, although the algorithm can in principle be applied to any high resolution TIR sounder with sufficient spectral resolution. It was specifically designed for quantifying high altitude $\mathrm{SO}_{2}$ plumes from volcanic eruptions. A first attractive feature of the algorithm is its robustness, simplicity and near real time applicability. With just a few lines of code this algorithm could for instance be implemented by volcanic ash advisory centers. Its second strong point is its very low theoretical uncertainty ( $3 \%$ uncertainty for $0.5-100 \mathrm{DU}$ and $6 \%$ for $100-5000 \mathrm{DU}$ for assumed altitudes above $500 \mathrm{hPa}$ ) coupled with a large applicable range ( 4 orders of magnitude of $\mathrm{SO}_{2}$ columns 0.5 to $5000 \mathrm{DU}$ ). By not using all IASI's channels the outlined algorithm does not exploit IASI's high spectral resolution to the fullest (for estimating plume altitude see Clarisse et al., 2008; for improved detection see Walker et al., 2011). Ideally therefore, these algorithms should be used in combination with each other.

Apart from this intrinsic uncertainty associated to the algorithm, the accuracy will be determined by knowledge of the plume altitude. This is especially the case in the mid troposphere where we have a large temperature gradient. Another source of error is the presence of (volcanic) aerosols and while the magnitude of the associated errors in the retrieval is hard to quantify, thin ash clouds will in general lead to slightly overestimated loadings, while thick opaque aerosol layers can cover up part or all $\mathrm{SO}_{2}$ and will give rise to underestimates.

Although a validation or comparison of this algorithm is out of the scope of this paper, we have illustrated the algorithm on a number of examples and found that the results were in agreement with the literature.

Acknowledgements. IASI has been developed and built under the responsibility of the Centre National d'Etudes Spatiales (CNES, France). It is flown onboard the Metop satellites as part of the EUMETSAT Polar System. The IASI L1 data are received through the EUMETCast near real time data distribution service. L. Clarisse and P.-F. Coheur are respectively Postdoctoral Researcher (Chargé de Recherches) and Research Associate (Chercheur Qualifié) with F.R.S.-FNRS. C. Clerbaux is grateful to CNES for scientific collaboration and financial support. The research in Belgium was funded by the F.R.S.-FNRS (M.I.S. nF.4511.08), the Belgian State Federal Office for Scientific, Technical and Cultural Affairs and the European Space Agency (ESA-Prodex arrangements and the Support to Aviation Control Service (SACS+) project). We also acknowledge financial support from the EVOSS project (2nd Space Call of the 7th Framework Program of the European Commission, with grant agreement 242535) and the "Actions de Recherche Concertées" (Communauté Française de Belgique). We would like to thank the referees for the many useful corrections and improvements.

Edited by: F. Prata

\section{References}

Andres, R. and Kasgnoc, A.: A time-averaged inventory of subaerial volcanic sulfur emissions, J. Geophys. Res., 103, 2525125261, 1998.

Bluth, G. J. S., Schnetzler, C. C., Krueger, A. J., and Walker, L. S.: The contribution of explosive volcanism to global atmospheric sulphur dioxide concentrations, Nature, 366, 327-329, 1993.

Bobrowski, N., Kern, C., Platt, U., Hörmann, C., and Wagner, T.: Novel $\mathrm{SO}_{2}$ spectral evaluation scheme using the 360 $390 \mathrm{~nm}$ wavelength range, Atmos. Meas. Tech., 3, 879-891, doi:10.5194/amt-3-879-2010, 2010.

Campion, R., Salerno, G. G., Coheur, P.-F., Hurtmans, D., Clarisse, L., Kazahaya, K., Burton, M., Caltabiano, T., Clerbaux, C., and Bernard, A.: Measuring volcanic degassing of $\mathrm{SO}_{2}$ in the lower troposphere with ASTER band ratios, J. Volcanol. Geoth. Res., 194, 42-54, doi:10.1016/j.jvolgeores.2010.04.010, 2010. 
Carn, S. A. and Lopez, T. M.: Opportunistic validation of sulfur dioxide in the Sarychev Peak volcanic eruption cloud, Atmos. Meas. Tech., 4, 1705-1712, doi:10.5194/amt-4-1705-2011, 2011

Carn, S. A. and Prata, F.: Satellite-based constraints on explosive $\mathrm{SO}_{2}$ release from Soufrière Hills Volcano, Montserrat, Geophys. Res. Lett., 37, L00E22, doi:10.1029/2010GL044971, 2010.

Carn, S. A., Strow, L., de Souza-Machado, S., Edmonds, Y., and Hannon, S.: Quantifying tropospheric volcanic emissions with AIRS: The 2002 eruption of Mt. Etna (Italy), Geophys. Res. Lett., 32, L02301, doi:10.1029/2004GL021034, 2005.

Carn, S. A., Krueger, A. J., Krotkov, N. A., Yang, K., and Evans, K.: Tracking volcanic sulfur dioxide clouds for aviation hazard mitigation, Nat. Hazards, 51, 325-343, 2009.

Chevallier, F.: Sampled databases of 60-level atmospheric profiles from the ECMWF analyses, Tech. rep., Eumetsat/ECMWF SAF Programme, Research Report No. 4, 2001.

Chin, M. and Jacob, D.: Anthropogenic and natural contributions to tropospheric sulfate: A global model analysis, J. Geophys. Res., 101, 18691-18699, 1996.

Clarisse, L., Coheur, P. F., Prata, A. J., Hurtmans, D., Razavi, A., Phulpin, T., Hadji-Lazaro, J., and Clerbaux, C.: Tracking and quantifying volcanic $\mathrm{SO}_{2}$ with IASI, the September 2007 eruption at Jebel at Tair, Atmos. Chem. Phys., 8, 7723-7734, doi:10.5194/acp-8-7723-2008, 2008.

Clarisse, L., Hurtmans, D., Prata, A. J., Karagulian, F., Clerbaux, C., Mazière, M. D., and Coheur, P.-F.: Retrieving radius, concentration, optical depth, and mass of different types of aerosols from high-resolution infrared nadir spectra, Appl. Optics, 49, 3713-3722, doi:10.1364/AO.49.003713, 2010a.

Clarisse, L., Prata, F., Lacour, J.-L., Hurtmans, D., Clerbaux, C., and Coheur, P.-F.: A correlation method for volcanic ash detection using hyperspectral infrared measurements, Geophys. Res. Lett., 37, L19806, doi:10.1029/2010GL044828, 2010 b.

Clarisse, L., Coheur, P.-F., Chefdeville, S., Lacour, J.-L., Hurtmans, D., and Clerbaux, C.: Infrared satellite observations of hydrogen sulfide in the volcanic plume of the August 2008 Kasatochi eruption, Geophys. Res. Lett., 38, L10804, doi:10.1029/2011GL047402, 2011a.

Clarisse, L., Fromm, M., Ngadi, Y., Emmons, L., Clerbaux, C., Hurtmans, D., and Coheur, P.-F.: Intercontinental transport of anthropogenic sulfur dioxide and other pollutants; an infrared remote sensing case study, Geophys. Res. Lett., 38, L19806, doi:10.1029/2011GL048976, 2011b.

Clerbaux, C., Coheur, P.-F., Clarisse, L., Hadji-Lazaro, J., Hurtmans, D., Turquety, S., Bowman, K., Worden, H., and Carn, $\mathrm{S}$.: Measurements of $\mathrm{SO}_{2}$ profiles in volcanic plumes from the NASA Tropospheric Emission Spectrometer (TES), Geophys. Res. Lett., 35, L22807, doi:10.1029/2008GL035566, 2008.

Clerbaux, C., Boynard, A., Clarisse, L., George, M., Hadji-Lazaro, J., Herbin, H., Hurtmans, D., Pommier, M., Razavi, A., Turquety, S., Wespes, C., and Coheur, P.-F.: Monitoring of atmospheric composition using the thermal infrared IASI/MetOp sounder, Atmos. Chem. Phys., 9, 6041-6054, doi:10.5194/acp-9-6041-2009, 2009.

Corradini, S., Merucci, L., and Prata, A. J.: Retrieval of $\mathrm{SO}_{2}$ from thermal infrared satellite measurements: correction procedures for the effects of volcanic ash, Atmos. Meas. Tech., 2, 177-191, doi:10.5194/amt-2-177-2009, 2009.
Corradini, S., Merucci, L., Prata, A. J., and Piscini, A.: Volcanic ash and $\mathrm{SO}_{2}$ in the 2008 Kasatochi eruption: Retrievals comparison from different IR satellite sensors, J. Geophys. Res., 115, D00L21, doi:10.1029/2009JD013634, 2010.

Doutriaux-Boucher, M. and Dubuisson, P.: Detection of volcanic $\mathrm{SO}_{2}$ by spaceborne infrared radiometers, Atmos. Res., 92, 6979, doi:10.1016/j.atmosres.2008.08.009, 2008.

Flaud, J.-M., Lafferty, W., and Sams, R.: Line intensities for the $v_{1}$, $v_{3}$, and $v_{1}+v_{3}$ bands of ${ }^{34} \mathrm{SO}_{2}$, J. Quant. Spectrosc. Ra., 110, 669-674, 2009.

Graf, H., Feichter, J., and Langmann, B.: Volcanic sulfur emissions: Estimates of source strength and its contribution to the global sulfate distribution, J. Geophys. Res., 102, 10727-10738, 1997.

Halmer, M., Schmincke, H.-U., and Graf, H.-F.: The annual volcanic gas input into the atmoshpere, in particular into the stratosphere: a global data set for the past 100 years, J. Volcanol. Geoth. Res., 115, 511-528, 2002.

Haywood, J. and Boucher, O.: Estimates of the direct and indirect radiative forcing due to tropospheric aerosols: a review, Rev. Geophys., 38, 513-543, 2000.

Haywood, J. M., Jones, A., Clarisse, L., Bourassa, A., Barnes, J., Telford, P., Bellouin, N., Boucher, O., Agnew, P., Clerbaux, C., Coheur, P., Degenstein, D., and Braesicke, P.: Observations of the eruption of the Sarychev volcano and simulations using the HadGEM2 climate model, J. Geophys. Res., 115, D21212, doi:10.1029/2010JD014447, 2010.

Karagulian, F., Clarisse, L., Clerbaux, C., Prata, A. J., Hurtmans, D., and Coheur, P. F.: Detection of volcanic $\mathrm{SO}_{2}$, ash and $\mathrm{H}_{2} \mathrm{SO}_{4}$ using the IASI sounder, J. Geophys. Res., 115, D00L02, doi:10.1029/2009JD012786, 2010.

Kravitz, B., Robock, A., Bourassa, A., Deshler, T., Wu, D., Mattis, I., Finger, F., Hoffmann, A., Ritter, C., Bitar, L., Duck, T. J., and Barnes, J. E.: Simulation and observations of stratospheric aerosols from the 2009 Sarychev volcanic eruption, J. Geophys. Res., 116, D18211, doi:10.1029/2010JD015501, 2011.

Kristiansen, N. I., Stohl, A., Prata, A. J., Richter, A., Eckhardt, S., Seibert, P., Hoffmann, A., Ritter, C., Bitar, L., Duck, T. J., and Stebel, K.: Remote sensing and inverse transport modeling of the Kasatochi eruption sulfur dioxide cloud, J. Geophys. Res., 115, D00L16, doi:10.1029/2009JD013286, 2010.

Krotkov, N., Schoeberl, M., Morris, G., Carn, S., and Yang, K.: Dispersion and lifetime of the $\mathrm{SO}_{2}$ cloud from the August 2008 Kasatochi eruption, J. Geophys. Res., 115, D00L20, doi:10.1029/2010JD013984, 2010.

Krueger, A., Walter, L., Bhartia, P., Schnetzler, C., Krotkov, N., Sprod, I., and Bluth, G.: Volcanic sulfur dioxide measurements from the Total Ozone Mapping Spectrometer (TOMS) Instruments., J. Geophys. Res., 100, 14057-14076, 1995.

Krueger, A., Krotkov, N., and Carn, S.: El Chichon: The genesis of volcanic sulfur dioxide monitoring from space, J. Volcanol. Geoth. Res., 175, 408-414, doi:10.1016/j.jvolgeores.2008.02.026, 2008.

Lee, C., Martin, R. V., van Donkelaar, A., Lee, H., Dickerson, R. R., Hains, J. C., Krotkov, N., Richter, A., Vinnikov, K., and Schwab, J. J.: $\mathrm{SO}_{2}$ emissions and lifetimes: Estimates from inverse modeling using in situ and global, space-based (SCIAMACHY and OMI) observations, J. Geophys. Res., 116, D06304, doi:10.1029/2010JD014758, 2011.

Longhurst, J. W., Raper, D. W., Lee, D. S., Heath, B. A., Con- 
lan, B., and King, H. J.: Acid deposition: a select review 18521990: 1. Emissions, transport, deposition, effects on freshwater systems and forests, Fuel, 72, 1261-1280, doi:10.1016/00162361(93)90125-L, 1993.

Matoza, R. S., Pichon, A. L., Vergoz, J., Herry, P., Lalande, J.M., Lee, H.-I., Che, I.-Y., and Rybin, A.: Infrasonic observations of the June 2009 Sarychev Peak eruption, Kuril Islands: Implications for infrasonic monitoring of remote explosive volcanism, J. Volcanol. Geoth. Res., 200, 35-48, doi:10.1016/j.jvolgeores.2010.11.022, 2011.

Prata, A.: Satellite detection of hazardous volcanic clouds and the risk to global air traffic, Nat. Hazards, 51, 303-324, doi:10.1007/s11069-008-9273-z, 2008.

Prata, A. and Bernardo, C.: Retrieval of volcanic $\mathrm{SO}_{2}$ column abundance from Atmospheric Infrared Sounder data, J. Geophys. Res., 112, D20204, doi:10.1029/2006JD007955, 2007.

Prata, A. and Kerkmann, J.: Simultaneous retrieval of volcanic ash and $\mathrm{SO}_{2}$ using MSG-SEVIRI measurements, Geophys. Res. Lett., 34, L05813, doi:10.1029/2006GL028691, 2007.

Prata, A., Rose, W., Self, S., and O'Brien, D.: Global, long-term sulphur dioxide measurements from TOVS data: A new tool for studying explosive volcanism and climate, in: Volcanism and the Earth's Atmosphere, edited by: Robock, A. and Oppenheimer, C., vol. 139 of Geophys. Monogr., 75-92, AGU, Washington, DC, 2003.

Prata, A., Gangale, G., Clarisse, L., and Karagulian, F.: Ash and sulfur dioxide in the 2008 eruptions of Okmok and Kasatochi: Insights from high spectral resolution satellite measurements, J. Geophys. Res., 115, D00L18, doi:10.1029/2009JD013556, 2010.

Realmuto, V., Abrams, M., Buongiorno, M., and Pieri, D.: The use of multispectral thermal infrared image data to estimate the sulfur dioxide flux from volcanoes: A case study from Mount Etna, Sicily, 29 July 1986, J. Geophys. Res., 99, 481-488, 1994.

Realmuto, V., Sutton, A., and Elias, T.: Multispectral thermal infrared mapping of sulfur dioxide plumes: A case study from the East Rift Zone of Kilauea Volcano, Hawaii, J. Geophys. Res., 102, 15057-15072, 1997.

Richter, A., Wittrock, F., Schönhardt, A., and Burrows, J.: Quantifying volcanic $\mathrm{SO}_{2}$ emissions using GOME2 measurements, Geophys. Res. Abstr., EGU2009-7679, EGU General Assembly 2009, Vienna, Austria, 2009.

Rix, M., Valks, P., Hao, N., van Geffen, J., Clerbaux, C., Clarisse, L., Coheur, P.-F., Loyola R, D. G., Erbertseder, T., Zimmer, W., and Emmadi, S.: Satellite Monitoring of Volcanic Sulfur Dioxide Emissions for Early Warning of Volcanic Hazards, IEEE J. Sel. Top. Appl., 2, 196-206, doi:10.1109/JSTARS.2009.2031120, 2009.

Robock, A.: Volcanic eruptions and climate, Rev. Geophys., 38, 191-219, 2000.

Rose, W. I., Bluth, G., and Watson, I.: Ice in volcanic clouds: When and where?, in: Proc. of the 2nd Int. Conf. on Volcanic Ash and Aviation Safety, OFCM, Washington, DC, Session 3, 61, Extended observations of volcanic $\mathrm{SO}_{2}$ and sulfate aerosol in the stratosphere, 2004.

Rothman, L., Gordon, I., Barbe, A., Benner, D., Bernath, P., Birk, M., Boudon, V., Brown, L., Campargue, A., Champion, J.-P., Chance, K., Coudert, L., Dana, V., Devi, V., Fally, S., Flaud, J.M., Gamache, R., Goldman, A., Jacquemart, D., Kleiner, I., La- come, N., Lafferty, W., Mandin, J.-Y., Massie, S., Mikhailenko, S., Miller, C., Moazzen-Ahmadi, N., Naumenko, O., Nikitin, A., Orphal, J., Perevalov, V., Perrin, A., Predoi-Cross, A., Rinsland, C., Rotger, M., Šimečková, M., Smith, M., Sung, K., Tashkun, S., Tennyson, J., Toth, R., Vandaele, A., and Auwera, J. V.: The HITRAN 2008 molecular spectroscopic database, Journal of Quantitative Spectroscopy and Radiative Transfer, 110, 533572, doi:10.1016/j.jqsrt.2009.02.013, 2009.

Rybin, A., Chibisova, M., Webley, P., Steensen, T., Izbekov, P., Neal, C., and Realmuto, V.: Satellite and ground observations of the June 2009 eruption of Sarychev Peak volcano, Matua Island, Central Kuriles, B. Volcanol., 1-16, doi:10.1007/s00445011-0481-0, 2011.

Smith, S. J., van Aardenne, J., Klimont, Z., Andres, R. J., Volke, A., and Delgado Arias, S.: Anthropogenic sulfur dioxide emissions: 1850-2005, Atmos. Chem. Phys., 11, 1101-1116, doi:10.5194/acp-11-1101-2011, 2011.

Surono, Jousset, P., Pallister, J., Boichu, M., Buongiorno, M., Budisantoso, A., Costa, F., Andreastuti, S., Prata, F., Schneider, D., Clarisse, L., Humaida, H., Sumarti, S., Bignami, C., Griswold, J., Carn, S., and Oppenheimer, C.: The 2010 explosive eruption of Javas Merapi volcano a 100-year event, submitted to J. Volcanol. Geoth. Res., 2012.

Thomas, H. and Watson, I.: Observations of volcanic emissions from space: current and future perspectives, Nat. Hazards, 54, 323-354, 2010.

Vernier, J.-P., Pommereau, J.-P., Thomason, L. W., Pelon, J., Garnier, A., Deshler, T., Jumelet, J., and Nielsen, J. K.: Overshooting of clean tropospheric air in the tropical lower stratosphere as seen by the CALIPSO lidar, Atmos. Chem. Phys., 11, 96839696, doi:10.5194/acp-11-9683-2011, 2011.

Walker, J. C., Dudhia, A., and Carboni, E.: An effective method for the detection of trace species demonstrated using the MetOp Infrared Atmospheric Sounding Interferometer, Atmos. Meas. Tech., 4, 1567-1580, doi:10.5194/amt-4-1567-2011, 2011.

Watson, I., Realmuto, V., Rose, W., Prata, A., Bluth, G., Gu, Y., Bader, C., and Yu, T.: Thermal infrared remote sensing of volcanic emissions using the moderate resolution imaging spectroradiometer, J. Volcanol. Geoth. Res., 135, 75-89, 2004.

Waythomas, C. F., Scott, W. E., Prejean, S. G., Schneider, D. J., Izbekov, P., and Nye, C. J.: The 7-8 August 2008 eruption of Kasatochi Volcano, central Aleutian Islands, Alaska, J. Geophys. Res., 115, B00B06, doi:10.1029/2010JB007437, 2010.

Yang, K., Krotkov, N., Krueger, A., Carn, S., Bhartia, P., and Levelt, P.: Retrieval of large volcanic $\mathrm{SO}_{2}$ columns from the Aura Ozone Monitoring Instrument: Comparison and limitations, J. Geophys Res., 112, D24S43, doi:10.1029/2007JD008825, 2007.

Zhang, Q., Jimenez, J. L., Canagaratna, M. R., Allan, J. D., Coe, H., Ulbrich, I., Alfarra, M. R., Takami, A., Middlebrook, A. M., Sun, Y. L., Dzepina, K., Dunlea, E., Docherty, K., DeCarlo, P. F., Salcedo, D., Onasch, T., Jayne, J. T., Miyoshi, T., Shimono, A., Hatakeyama, S., Takegawa, N., Kondo, Y., Schneider, J., Drewnick, F., Borrmann, S., Weimer, S., Demerjian, K., Williams, P., Bower, K., Bahreini, R., Cottrell, L., Griffin, R. J., Rautiainen, J., Sun, J. Y., Zhang, Y. M., and Worsnop, D. R.: Ubiquity and dominance of oxygenated species in organic aerosols in anthropogenically-influenced Northern Hemisphere midlatitudes, Geophys. Res. Lett., 34, L13801, doi:10.1029/2007GL029979, 2007. 